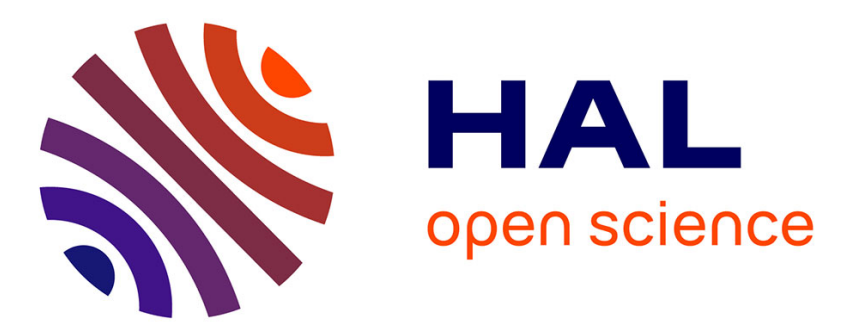

\title{
High sorption of phenanthrene in agricultural soils
}

Samira Amellal, Arnaud Boivin, Corinne Perrin-Ganier, Michel Schiavon

\section{To cite this version:}

Samira Amellal, Arnaud Boivin, Corinne Perrin-Ganier, Michel Schiavon. High sorption of phenanthrene in agricultural soils. Agronomy for Sustainable Development, 2006, 26 (2), pp.99-106. 10.1051/agro:2006002 . hal-02667608

\section{HAL Id: hal-02667608 https: / hal.inrae.fr/hal-02667608}

Submitted on 31 May 2020

HAL is a multi-disciplinary open access archive for the deposit and dissemination of scientific research documents, whether they are published or not. The documents may come from teaching and research institutions in France or abroad, or from public or private research centers.
L'archive ouverte pluridisciplinaire HAL, est destinée au dépôt et à la diffusion de documents scientifiques de niveau recherche, publiés ou non, émanant des établissements d'enseignement et de recherche français ou étrangers, des laboratoires publics ou privés.

$$
\text { Copyright }
$$


Research article

\title{
High sorption of phenanthrene in agricultural soils
}

\author{
Samira AmEllat*, Arnaud Boivin, Corinne PERRIN GANIER, Michel Schiavon \\ Laboratoire Sols et Environnement, ENSAIA-INRA/INPL, 2 avenue de la Forêt de Haye, BP 172, 54505 Vandœuvre-lès-Nancy Cedex, France
}

(Accepted 16 January 2006)

\begin{abstract}
We studied the sorption and desorption of ${ }^{14} \mathrm{C}$-labelled phenanthrene, a polycyclic aromatic hydrocarbon, on soils, both in the laboratory using batch experiments and during 6 months of natural conditions using lysimeters. The laboratory results show that phenanthrene is strongly adsorbed, yielding empirical constants of sorption isotherms $\mathrm{K}_{\mathrm{f}}$ of 163 for the clay soil and of 77 for the sandy loam soil. This result is unexpected because phenanthrene has a relatively high water solubility of $1.1 \mathrm{mg} / \mathrm{L}$. Phenanthrene is also poorly desorbed, as shown by leaching of only $30 \%$ of initially sorbed phenanthrene. The natural condition results show that $27 \%$ of the initial phenanthrene occurs as nonavailable, bound residues after 6 months. The leaching of ${ }^{14} \mathrm{C}$ phenanthrene derivatives amounts to less than $2 \%$ of the applied phenanthrene. The ${ }^{14} \mathrm{C}$ phenanthrene derivatives leached included $80 \%$ of polar products. Analysis of the extractable residues from soils by high-performance liquid chromatography (HPLC) showed the occurrence of 9,10-phenanthrenedione, a toxic degradation product, in notable quantities of 2-3\% of extractable compounds.
\end{abstract}

PAH / adsorption / desorption / leaching / agricultural soil / water quality

\section{INTRODUCTION}

A major issue of the 21 st century is to know whether soil resources, as well as water resources, will be sufficient for a growing population. A major concern is the protection of water resources from contaminants (Lichtfouse et al., 2005). Recently, environmental contamination by persistent organic compounds has become a matter of great concern. Polycyclic aromatic hydrocarbons (PAHs) have been of great interest due to their carcinogenic and mutagenic properties (Perera, 1997).

Soil systems are one of the main repositories for atmospheric PAHs (Wild and Jones, 1995; Lichtfouse et al., 1997). Once deposited, PAHs can persist for more than 20 years (Wild et al., 1990), and their accumulation in agricultural soils may lead to contamination of food chains (Laurent et al., 2002; SamsøePetersen et al., 2002). Indeed, PAHs are subject to redistribution and transformation processes. PAH persistence in soils is thought to be a consequence of their affinity for soil organic matter (Wilcke et al., 1996). Sorption and degradation are key processes that affect the fate and transport of PAHs in the environment (Magee et al., 1991). The degradation catalysed by soil microorganisms is controlled by both abiotic and biotic factors (Johnsen et al., 2004). Degradation is affected by a variety of interactions between microorganisms, various soil constituents and the specific PAH involved. Sorption also plays a key role in controlling transport of PAHs during leaching, as well as in transformation and bio-accumulation processes (Reeves et al., 2004).
On the other hand, preferential water flow can enhance the transport of organic pollutants to the deeper layers (Zehe and Fluhler, 2001). If upland soil is frequently irrigated or saturated with water for a significant part of the year, there is an increased leaching of PAHs from contaminated sites to the deeper layers, thereby endangering groundwater quality (Weigand et al., 2001). To avoid any risk of food production and to limit the damaging effect of these contaminants on the ecosystem, a wide-ranging investigation of soil contamination by PAHs is needed.

Up to now, most knowledge of the distribution of PAHs in the environment has derived from studies focusing on industrial soils and sediments (Fent, 2004), while information on the state of PAH contamination of agricultural soils is scarce (Jones et al., 1989). Rapid industrialisation over recent decades has resulted in many environmental problems. Increasing traffic associated with population growth in metropolitan areas can also result in an increase in PAH concentrations and consequently deposition on agricultural soils (Barriuso et al., 1996; Crépineau-Ducoulombier and Rychen, 2003). This highlights the need for better evaluation of the leaching potential of phenanthrene and of PAH behaviour in general in agricultural soils.

The aims of this study were to assess the dynamic interactions between phenanthrene sorption and leaching and to identify the main factors that influence the two processes. To this end, an experiment was carried out under natural climatic conditions using a microlysimeter with two objectives: (1) to

* Corresponding author: Samira.Amellal@ensaia.inpl-nancy.fr 
Table I. Characteristics of the soils (surface layers, 0-15 cm) used in this study. OC: Organic Carbon content (\%); C/N: Organic carbon/organic nitrogen ratio; CEC: Cationic Exchange Capacity $(\mathrm{cmol} / \mathrm{kg})$.

\begin{tabular}{|c|c|c|c|c|c|c|c|c|}
\hline Soil type & $\begin{array}{l}\text { Clay } \\
(\%)\end{array}$ & $\begin{array}{l}\text { Silt } \\
(\%)\end{array}$ & $\begin{array}{l}\text { Sand } \\
(\%)\end{array}$ & $\begin{array}{l}\mathrm{pH} \\
\mathrm{H}_{2} \mathrm{O}\end{array}$ & $\begin{array}{l}\mathrm{OC} \\
(\%)\end{array}$ & $\mathrm{C} / \mathrm{N}$ & $\begin{array}{c}\mathrm{CEC} \\
(\mathrm{cmol} / \mathrm{kg})\end{array}$ & $\begin{array}{c}\text { Phenanthrene } \\
\mu \mathrm{g} / \mathrm{kg}\end{array}$ \\
\hline Clay soil & 41.1 & 48.6 & 10.3 & 7.1 & 1.9 & 9.9 & 18.7 & 16 \\
\hline Sandy loam soil & 12.7 & 13.8 & 73.5 & 6.4 & 0.8 & 10.1 & 4.6 & 23 \\
\hline
\end{tabular}

Table II. Some physical characteristics of the soils.

\begin{tabular}{lcccc}
\hline $\begin{array}{l}\text { Soil } \\
\text { type }\end{array}$ & $\begin{array}{c}\text { Density } \\
\mathrm{g} / \mathrm{cm}^{3}\end{array}$ & $\begin{array}{c}\text { Infiltration rate } \\
\mathrm{mm} / \mathrm{min} / \mathrm{cm}^{2}\end{array}$ & $\begin{array}{c}\text { Macroporosity } \\
\mathrm{cm}^{3} / \mathrm{cm}^{3}\end{array}$ & $\begin{array}{c}\text { Microporosity } \\
\mathrm{cm}^{3} / \mathrm{cm}^{3}\end{array}$ \\
\hline Clay soil & $1.06 \pm 0.04$ & $2.59 \pm 0.03$ & $0.19 \pm 0.014$ & $0.33 \pm 0.008$ \\
\hline Sandy loam soil & $1.01 \pm 0.02$ & $24.38 \pm 0.87$ & $0.32 \pm 0.021$ & $0.16 \pm 0.012$ \\
\hline
\end{tabular}

examine the leaching of phenanthrene in two agricultural soils with contrasting bio-physico-chemical parameters, a clay and a sandy loam, and (2) to provide information concerning the effects of sorption/desorption and the physical parameters of soils on phenanthrene transport by leaching.

\section{MATERIALS AND METHODS}

\subsection{Chemicals}

[Benzene ring-U ${ }^{14} \mathrm{C}, 9-{ }^{14} \mathrm{C}$ ]-phenanthrene was obtained from American Radiolabeled Chemicals and diluted in ethanol. Its specific radioactivity was $2.035 \mathrm{GBq} / \mathrm{mmol}$ and its radiochemical purity $99.8 \%$. Non-radioactive phenanthrene (purity 99.7\%) was obtained from ACROS ORGANICS New Jersey, USA: 1-800-ACROS-01. $\mathrm{CaCl}_{2} 2 \mathrm{H}_{2} \mathrm{O}$ was purchased from Prolabo (purity: 98\%). All solvents were of high-performance liquid chromatography (HPLC) grade.

\subsection{Selected soils}

The surface layers of two cultivated soils were sampled ( 0 $15 \mathrm{~cm})$. They were selected on the basis of their texture and organic matter contents (Tab. I) (Jacquin and Florentin, 1988). The two soils came from the Lorraine region in eastern France. Soil types were classified into vertic stagnic cambisol, hereafter referred to as 'clay soil', and eutric combisol, hereafter referred to as sandy loam soil (Batjes, 1998). Soil samples were airdried, sieved through 2-mm or 5-mm mesh size depending on the experiment, stored in the dark at room temperature $(20 \pm$ $2{ }^{\circ} \mathrm{C}$ ) and protected from humidity. Some physical characteristics of the soils were measured in the laboratory before use: density, infiltration rate at saturation and porosity (Tab. II).

Infiltration rate was determined under a $10 \mathrm{~mm}$ depth of water (Guennelon, 1994). Macroporosity (difference between waterlogged soil and moisture retention capacity) and microporosity (difference between moisture retention capacity and moisture at wilting point) were measured by weighing according to the method described by Monnier (1994).

\subsection{Selected phenanthrene solutions}

Aqueous phenanthrene solutions for sorption experiments were prepared in $0.01 \mathrm{M} \mathrm{CaCl}_{2}$. Total phenanthrene concentrations were $13 ; 120 ; 227 ; 441$ and $547 \mu \mathrm{g} / \mathrm{L}$ (water solubility of phenanthrene $=1290 \mu \mathrm{g} / \mathrm{L}$ ). To each of these stock solutions $13 \mu \mathrm{g} / \mathrm{L}$ of ${ }^{14} \mathrm{C}$-phenanthrene were added, giving an activity of $1.5 \times 10^{5} \mathrm{~Bq} / \mathrm{L}$.

\subsection{Laboratory sorption and desorption experiments}

Sorption experiments were carried out using the standard batch equilibration method (OECD guideline 106, 2000) as described below. According to the results of previous kinetic studies, the soil weight/solution volume ratio was adjusted to $1 / 20(\mathrm{~W} / \mathrm{V})$ and the equilibrium was assumed to be reached within the 16-h equilibration period (results not shown).

In the first stage, $20 \mathrm{~mL}$ of aqueous calcium chloride $\left(\mathrm{CaCl}_{2}\right.$, $0.01 \mathrm{M}$ ) were added to $1 \mathrm{~g}$ of air-dried soil, sieved at $2 \mathrm{~mm}$, in 25-mL Corex ${ }^{\mathrm{TM}}$ glass centrifuge tubes, in order to bring the samples to water saturation. Tubes were shaken with a rotary agitator $(60 \mathrm{rpm})$ for $1 \mathrm{~h}$ at $20 \pm 2{ }^{\circ} \mathrm{C}$ in the dark and then centrifuged at $5000 \mathrm{~g}$ for 25 min using an Avanti ${ }^{\mathrm{TM}} \mathrm{J}-25$ (Beckman Instruments, Inc, Fullerton, CA, USA). Next, supernatants were removed $(18 \pm 0.01 \mathrm{~mL})$ and replaced by labelled phenanthrene solutions, after which the tubes were shaken again (same conditions as those described above). Samples were then centrifuged as described above. Three replicates were made for each concentration. The radioactivity of the supernatant was measured using a 1900 Tri-carb liquid scintillation analyser (Packard) after adding $10 \mathrm{~mL}$ of a scintillation cocktail (UltimaGold ${ }^{\mathrm{TM}}$, Packard Bioscience). The counting time was $10 \mathrm{~min}$ and a quench correction was made by the scintillator analyser after calibration. Several tubes without soil were also shaken as controls. These showed a negligible loss $(1.1 \pm 0.2 \%)$ of ${ }^{14} \mathrm{C}$. Thus, differences between the initial and equilibrium concentrations were assumed to be due to sorption onto soil. Sorption isotherms were obtained by plotting the amount of phenanthrene sorbed per weight of soil at equilibrium $\left(Q_{e}, \mu g / g\right)$ versus the amount of phenanthrene per volume of solution at equilibrium $\left(\mathrm{C}_{\mathrm{e}}, \mu \mathrm{g} / \mathrm{mL}\right)$. The sorption data were described using the Freundlich equation. 


$$
\mathrm{Q}_{\mathrm{e}}=\mathrm{K}_{\mathrm{f}} \cdot \mathrm{C}_{\mathrm{e}}^{\mathrm{nf}}
$$

where $Q_{e}$ is the concentration of phenanthrene sorbed on the solid phase $(\mu \mathrm{g} / \mathrm{g}), \mathrm{C}_{\mathrm{e}}$ is the concentration of phenanthrene in solution at equilibrium $(\mu \mathrm{g} / \mathrm{mL})$, and $\mathrm{K}_{\mathrm{f}}$ (in $\mu \mathrm{g}^{1-\mathrm{nf}} \mathrm{mL}^{\mathrm{nf}} \mathrm{g}^{-1}$ ) and $\mathrm{nf}$ are empirical constants which are related to the adsorption phenomenon and calculated by regression analysis. $\mathrm{K}_{\mathrm{f}}$ can be considered as a characterisation of the intensity of sorption, modulated by the deviation from the unity of the $\mathrm{nf}$ exponent (Coquet, 2002; Saison et al., 2004).

Desorption experiments were conducted immediately after the sorption experiments, starting at a concentration of $0.244 \pm$ $0.06 \mu \mathrm{g}$ phenanthrene/g soil for the clay soil and $0.234 \pm$ $0.07 \mu \mathrm{g} / \mathrm{g}$ for the sandy loam soil. First, supernatants were replaced with aqueous calcium chloride solution free of phenanthrene $(0.01 \mathrm{M}, 18 \mathrm{~mL})$, and the tubes were shaken at $20 \pm$ $2{ }^{\circ} \mathrm{C}$ for $16 \mathrm{~h}$. During the preparation of the different replicates, the tubes were stored in the fridge at $5{ }^{\circ} \mathrm{C}$ to avoid bio-degradation. The suspensions were subsequently centrifuged and the radioactivity of the supernatant solution was measured (in the same way as for the sorption experiments). Five successive desorption steps were performed using the procedure described above.

\subsection{Experiment under natural climatic conditions}

\subsubsection{Soil spiking with ${ }^{14}$-phenanthrene}

One hundred grams of each soil sieved at $5 \mathrm{~mm}$ were spiked with ${ }^{14} \mathrm{C}$-phenanthrene. The ${ }^{14} \mathrm{C}$-phenanthrene was added as a 2 -mL acetonitrile solution at a concentration of $0.204 \mu \mathrm{g} / \mathrm{g}$ soil, corresponding to $2.33 \mathrm{kBq} / \mathrm{g}$ soil. The solution was added as microdrops onto the soil surface and after evaporation of the solvent, the sample was thoroughly mixed. Three replicates were performed for each soil and for each of the five measuring times used during the course of the experiment.

\subsubsection{Microlysimeter}

The soils were placed in polyvinyl chloride cylinders coated with an aluminium film $(\varnothing 5 \mathrm{~cm} \times 5 \mathrm{~cm}$ high). A glass funnel was fixed on the bottom of the microlysimeter and led water from the lysimeter to a $500-\mathrm{mL}$ glass bottle which was protected from light. A total of 30 microlysimeters were run for 6 months in outdoor conditions at Vandœuvre-lès-Nancy (France). This area has an oceanic climate with continental influence (average temperature: $10^{\circ} \mathrm{C}$, min: $1.5^{\circ} \mathrm{C}$, max: $18.5^{\circ} \mathrm{C}$; precipitation: $700-900 \mathrm{~mm} / \mathrm{year}$ ). The sites received natural rainfall (547 $\mathrm{mm}$ in 6 months) which generated 7 leachates. After $0,15,30,90$ and 180 days three microlysimeters were removed for each soil type. The soils were then subjected to analysis.

\subsubsection{Leachate collection}

Leachates were collected from each microlysimeter after each rainfall event. The volume of each single leachate was measured. The leached radioactivity was counted by a liquid scintillation Packard TriCarb 2100 TR ( $1 \mathrm{~mL}$ of water in $10 \mathrm{~mL}$ of Ultima Gold - Packard) with background noise and quench correction. This measurement allowed quantitative evaluation of the leaching residues (phenanthrene and degradation products) for each microlysimeter.

\subsubsection{Nature of ${ }^{14} \mathrm{C}$-compounds in the leachates}

For each rainfall event, the leachates of all the replicates of one soil were pooled. ${ }^{14} \mathrm{C}$-labelled compounds in the leachates were extracted from $400 \mathrm{~mL}$ of the sample with $80 \mathrm{~mL}$ of dichloromethane by liquid/liquid partitioning. Three successive extractions were performed, each lasting for $10 \mathrm{~min}$ (this method gave an extraction rate of $96 \pm 3.5 \%$ of phenanthrene from pure water). At the end of the procedure, some of the ${ }^{14} \mathrm{C}$ compounds remained in the water and these are hereafter referred to as "polar compounds". Those dissolved in solvent are referred to as "non-polar compounds". The relative distribution of polar and non-polar compounds was calculated after analysis of the extracts by liquid scintillation as described above.

\subsubsection{Extractable ${ }^{14}$ C-compounds from the soils and analysis}

Preliminary tests were carried out to choose the most efficient solvent to extract ${ }^{14} \mathrm{C}$-compounds from soil (data not shown). Methanol was chosen because it allowed the best extraction yield of ${ }^{14} \mathrm{C}$-compounds on moist soils (86.3 \pm $2.5 \%$ ). Thus, $100 \mathrm{~mL}$ of methanol were added to $50-\mathrm{g}$ soil samples and the samples were then rotary shaken at $20 \pm 2{ }^{\circ} \mathrm{C}$ for $20 \mathrm{~h}$ in Corex ${ }^{\mathrm{TM}}$ glass centrifuge flasks. The samples were next centrifuged at $5000 \mathrm{~g}$ for $20 \mathrm{~min}$ and the radioactivity of $1 \mathrm{~mL}$ of supernatant determined using liquid scintillation as before. This process was repeated until the supernatant radioactivity was less than three times the background noise of the scintillator analyser $(1.7 \mathrm{~Bq})$.

After extraction, the supernatants of the replicates were combined and then concentrated for analysis of degradation products by high-performance liquid chromatography (HPLC) in a Varian chromatograph equipped with a diode array detector and $\beta$-radioactivity detector (Flo-one $\beta$, Packard) with the following operating conditions: $\mathrm{C} 18$ column $4.6 \times 250 \mathrm{~mm}$ spheri ODS $5 \mu$ (Perkin Elmer), injection volume $50 \mu \mathrm{L}$, analysis time $28 \mathrm{~min}$, flow rate $0.8 \mathrm{~mL} / \mathrm{min}$, gradient elution acetonitrile/ water: $0 \mathrm{~min}$ (50/50), $3 \mathrm{~min}$ (60/40), $15 \mathrm{~min}$ (90/10) and $21 \mathrm{~min}$ (95/5). Detection was performed in the following conditions: (1) $\beta$ radioactivity detector: Scintillator Ultima-Flo, flow $1.2 \mathrm{~mL} /$ min, counting cell $500 \mu \mathrm{L}$ and (2) diode array detector: wavelength $249 \mathrm{~nm}$, standards of the phenanthrene and 9,10-phenanthrenedione (mixed with acetonitrile) (Cluzeau France, Purity $>99 \%)$ for calibration $(10,7.5,5,2.5$ and $1.225 \mu \mathrm{g} / \mathrm{L})$. The retention times were 7.5 and $17 \mathrm{~min}$ for 9,10-phenanthrenedione and phenanthrene, respectively.

\subsubsection{Non-extractable ${ }^{14}$ C-compounds from the soils}

After exhaustive extraction, all soil samples were air-dried. Remaining non-extractable ${ }^{14} \mathrm{C}$-compounds were determined by combustion. An aliquot of $0.3 \mathrm{~g}$ was mixed with $0.15 \mathrm{mg}$ of cellulose powder and the sample was burnt at $900^{\circ} \mathrm{C}$ with a 307 Packard Oxidizer. The evolved $\mathrm{CO}_{2}$ was trapped with $10 \mathrm{~mL}$ 
Table III. Changes in ${ }^{14} \mathrm{C}$-phenanthrene adsorption parameters $\left(\mathrm{K}_{\mathrm{d}}=\mathrm{Qe}(\mu \mathrm{g} / \mathrm{g}) / \mathrm{Ce}(\mu \mathrm{g} / \mathrm{mL})\right.$ and $\mathrm{K}_{\mathrm{oc}}=\left(\mathrm{K}_{\mathrm{d}} / \%\right.$ organic carbon $\left.) \times 100\right)$ according to the ${ }^{14} \mathrm{C}$-phenanthrene concentrations in contact with the soils.

\begin{tabular}{lcccccc}
\hline & & \multicolumn{4}{c}{ Initial phenanthrene concentrations (mg/L) } \\
& & 0.013 & 0.120 & 0.227 & 0.441 & 0.547 \\
\hline Clay soil & $\mathrm{K}_{\mathrm{d}}$ & 300 & 264 & 257 & 230 & 192 \\
$(\mathrm{OC}=1.9 \%)$ & $\mathrm{K}_{\mathrm{oc}}$ & 15798 & 13920 & 13513 & 11564 & 10105 \\
Sandy loam soil & $\mathrm{K}_{\mathrm{d}}$ & 180 & 128 & 117 & 106 & 109 \\
$(\mathrm{OC}=0.8 \%)$ & $\mathrm{K}_{\mathrm{oc}}$ & 22537 & 15982 & 14625 & 13267 & 13683 \\
\hline
\end{tabular}

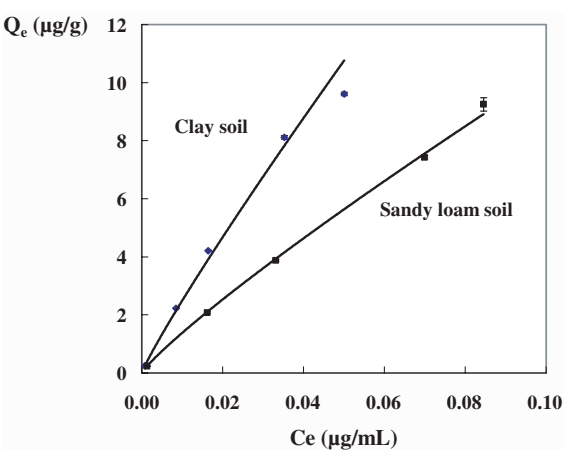

Figure 1. Adsorption isotherms of ${ }^{14} \mathrm{C}$-phenanthrene for clay soil $\left(\mathrm{Qe}=163.6 \mathrm{Ce}^{0.91} ; \mathrm{R}^{2}=0.99\right)$ and sandy loam soil $\left(\mathrm{Qe}=77.26 \mathrm{Ce} \mathrm{e}^{0.87}\right.$ $\mathrm{R}^{2}=0.99$ ). (Dots: experimental data, lines: Freundlich model). The standard deviation is not visible.

Carbosorb (Packard) and the radioactivity was counted after the addition of $10 \mathrm{~mL}$ of Permafluor (Packard).

\subsubsection{Statistics}

Statistics were run using Stat Box computer software (Grimmer Software version 6.4). ANOVA and comparison of means were done using the Newman-Keuls test at levels of 0.05, 0.01 and 0.001 .

\section{RESULTS AND DISCUSSION}

\subsection{Sorption of phenanthrene}

Sorption of phenanthrene on soils was studied using the standard batch equilibration method. The phenanthrene adsorption isotherms for the clay and sandy loam soils under our working conditions ( $1 \mathrm{~g}$ of soil/20 $\mathrm{mL}$ aqueous phenanthrene solution) are presented in Figure 1. The high correlation coefficients $\left(\mathrm{r}^{2}>0.99\right)$ obtained for the two soils show that the data can be accurately described by the Freundlich model. The values of the $n f$ coefficients (described before), $0.91 \pm 0.01$ for the clay soil and $0.87 \pm 0.02$ for sandy loam soil, displayed a slight curvature of the adsorption isotherms. Such values, in particular for the sandy loam soil, are usually interpreted as a decrease in the number of sites that are easily accessible to phenanthrene when the equilibrium concentration increases (Chiou et al., 2000).
Calculation of the sorption partition coefficient $\left(\mathrm{K}_{\mathrm{d}}\right)$ confirmed the phenomena (Tab. III). The $\mathrm{K}_{\mathrm{f}}$ parameter of the Freundlich model (slope of the sorption isotherm) expresses soil sorption capacity for a given range of phenanthrene concentrations. In our study, $\mathrm{K}_{\mathrm{f}}$ values ranged from 163 for the clay soil to 77 for the sandy loam soil (Fig. 1). The highest $\mathrm{K}_{\mathrm{f}}$ value was observed in the clay soil, which also had the highest organic carbon (OC) content. The $\mathrm{K}_{\mathrm{f}}$ value reported here is higher than that reported by Saison et al. (2004) for another agricultural soil ("Bouzule" with $0.87 \%$ of OC) which is $\mathrm{K}_{\mathrm{f}}: 8.55$, perhaps because of the nature of its organic matter. For a better assessment of the sorption affinity of the different soils, the carbon normalised distribution ratio $\mathrm{K}_{\mathrm{oc}}$ was calculated for every phenanthrene concentration (Tab. III). The $\mathrm{K}_{\mathrm{oc}}$ value for the $0.013 \mathrm{mg} / \mathrm{L}$ initial concentration was 15798 for the clay soil and 22537 for the sandy loam soil. $\mathrm{K}_{\mathrm{oc}}$ coefficients obtained with the sandy loam soil showed that its organic matter was more effective for phenanthrene sorption than that of the clay soil. Thus, for the lowest concentration used $(0.013 \mathrm{mg} / \mathrm{L})$ the adsorbed quantities were $0.244 \pm 0.06 \mu \mathrm{g} / \mathrm{g}$ for the clay soil and $0.234 \pm 0.09 \mu \mathrm{g} / \mathrm{g}$ for the sandy loam soil. These values are very close and represent $93.8 \%$ of phenanthrene previously in solution in the clay soil and $90.0 \%$ in the sandy loam soil. So, at low concentrations, the capacity for phenanthrene adsorption is similar in the two soils and almost total.

\subsection{Desorption behaviour of phenanthrene}

In addition to sorption experiments that provide information about the amounts of product retained by soil, more knowledge is required about desorption as it controls the likelihood of PAHs to return to the water phase where they are degraded and/ or leached. For that, the samples of soil carrying adsorbed phenanthrene were subjected to five successive desorption steps with $\mathrm{CaCl}_{2} 0.01 \mathrm{M}$. Our experimental data showed that desorption was only slight: 27.2 and $33.4 \%$ of initially sorbed phenanthrene were desorbed from the clay and sandy loam soils, respectively, during the 5 successive desorption steps (Tab. IV). These values indicate a strong hysteresis which remained relatively constant during the first 3 steps of desorption. Hysteresis is evidenced by an increase in the difference between the adsorption and desorption isotherm slopes and has been well documented (Worrall et al., 2001). Our observations indicated that the desorbed quantities depend on the energy provided to ensure desorption and are limited by the solubility of phenanthrene. The desorbed percentages decreased during the last 2 desorption steps, perhaps because (1) desorption concerns 
Table IV. Percentage of phenanthrene desorbed during the 5th step of desorption as a function of the initial quantities adsorbed on the two soils. The letters correspond to the homogeneous groups given by the comparison of means with the Newman-Keuls test $(P<0.05)$.

\begin{tabular}{lccccccc}
\hline Initially sorbed phenanthrene $\mu \mathrm{g} / \mathrm{g}$ & \multicolumn{5}{c}{$\begin{array}{c}\text { \% desorbed phenanthrene } \\
\text { desorption steps }\end{array}$} \\
& & 1 & 2 & 3 & 4 & 5 & Total \\
\hline Clay soil & $0.244 \pm 0.06 \mu \mathrm{g} / \mathrm{g}$ & $6.02 \pm 0.47$ & $5.99 \pm 0.45$ & $6.23 \pm 0.24$ & $5.32 \pm 0.65$ & $3.67 \pm 0.43$ & $27.23 \mathrm{a}$ \\
\hline Sandy loam soil & $0.234 \pm 0.07 \mu \mathrm{g} / \mathrm{g}$ & $6.88 \pm 0.17$ & $7.06 \pm 0.09$ & $7.13 \pm 0.15$ & $6.73 \pm 0.06$ & $5.63 \pm 0.19$ & $33.43 \mathrm{a}$ \\
\hline
\end{tabular}

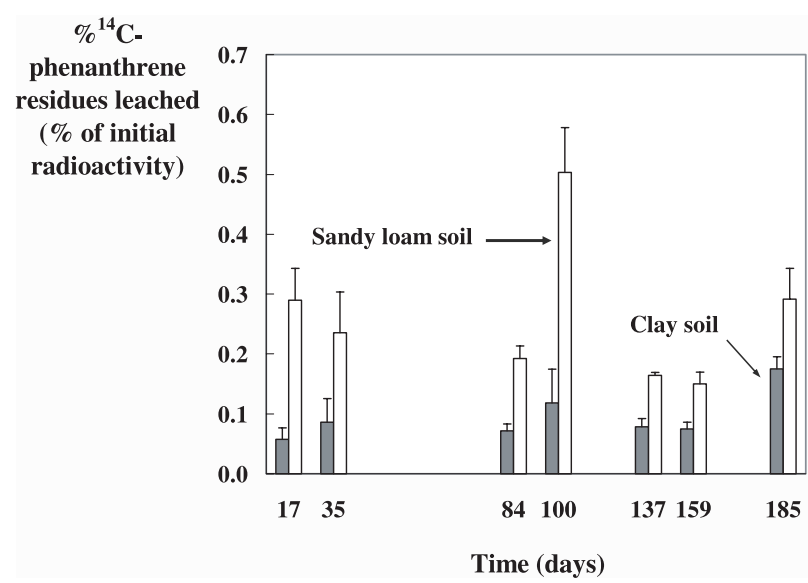

Figure 2. Weak leaching of ${ }^{14} \mathrm{C}$-phenanthrene residues from two soils during a period of 185 days under natural climatic conditions. The standard deviations indicate significant differences in the means of around $5 \%$.

residues with stronger soil-phenanthrene interactions, and (2) the sorption sites are less accessible to $\mathrm{CaCl}_{2}$. In our study, for the small initial quantities adsorbed, there was no significant difference between the two soils in the percentage desorbed (Tab. IV).

The experiment enabled us to conclude that (1) sorption increases with the organic content but not proportionally $\left(\mathrm{K}_{\mathrm{f}}\right.$ values ranged from 163 for clay soil, to 77 for sandy loam soil), (2) the organic matter content is not the only key parameter (the organic matter of the clay soil is less efficient than that of the sandy loam in binding phenanthrene at similar organic carbon contents) and (3) at low phenanthrene concentrations, sorption and desorption rates are independent of soil characteristics in our experimental conditions.

It is noteworthy that the phenanthrene concentration used in the microlysimeter was chosen as a function of the results of the adsorption/desorption experiments. This was to allow for the possible influence of the physical properties of the soil on leaching of phenanthrene.

\subsection{Leaching of ${ }^{14} \mathrm{C}$-phenanthrene residues}

The results presented in Figure 2 show that leaching of ${ }^{14} \mathrm{C}$ phenanthrene residues from the two soils was very low, although significantly greater in the sandy loam soil than in the clay soil $(P<0.05)$. After 6 months, less than $2 \%$ of radioac-

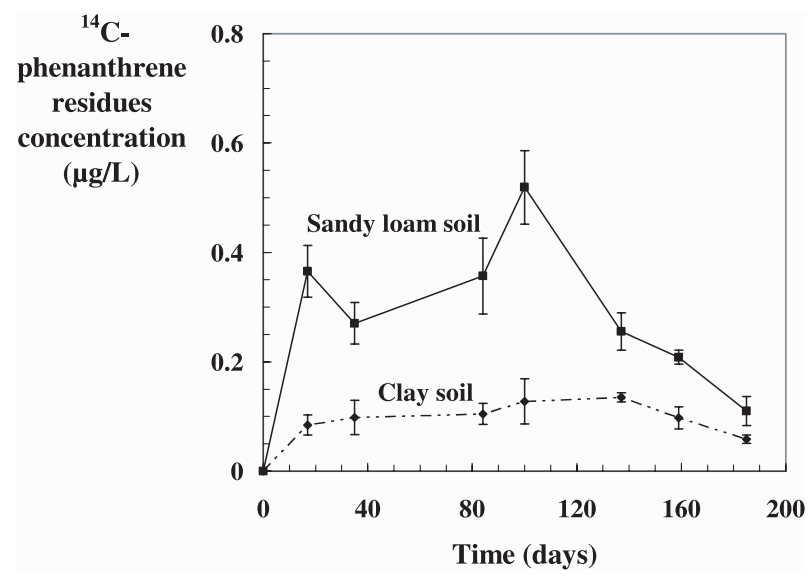

Figure 3. Evolution of ${ }^{14} \mathrm{C}$-phenanthrene residue concentration in the leachates during the course of the experiment. The concentration is calculated from radioactivity of the solution for ${ }^{14} \mathrm{C}$-compounds' molecular weight equal to that of phenanthrene. The standard deviations indicate significant differences of the means of around 5\%.

tivity leached from the soils. Moreover, the highest concentration of ${ }^{14} \mathrm{C}$ - phenanthrene residues (Fig. 3) calculated in the leachates of the sandy loam soil $(0.52 \mu \mathrm{g} / \mathrm{L})$ was 2000 times lower than the solubility of phenanthrene in water. In fact, for clay soil, it was the same as the concentration of solutions in equilibrium (lowest concentration) in the sorption/desorption experiment.

These results indicate that the length of soil-water contact during percolation allows desorption of phenanthrene residues but also its subsequent adsorption, in particular in clay soil, for which the infiltration rate is slow. In addition, the conditioning of the dry soil by sieving into 5-mm aggregates gave each soil approximately the same density and macroporosity (Tab. II) and thus the same water infiltration rate on dry soil.

However, at the moment leaching occurs, the volume of the clay increases by $13.5 \%$ due to the expansion of clays during moistening. Thus, its water infiltration rate is lower than that of the sandy loam soil. Therefore, we suggest that under natural climatic conditions, the infiltration rates of water in these soils are close to those measured in the laboratory using saturation techniques (Tab. II). For this reason, except during the first rain on dry soil, the infiltration rate is approximately 10 times lower in the clay soil than in the sandy loam soil.

The infiltration rate combined with the soil structure seems to be an important parameter in the leaching of phenanthrene. In addition, the periodicity and the intensity of the rainfall 
Table V. Products (\% of ${ }^{14} \mathrm{C}$-compounds extracted) recovered using methanol extraction. Three groups of chemicals were examined: ${ }^{14} \mathrm{C}-$ phenanthrene, 9,10-phenanthrenedione and "Others".

\begin{tabular}{|c|c|c|c|c|c|c|}
\hline & \multicolumn{5}{|c|}{ Time (days) } \\
\hline & & 0 & 15 & 30 & 90 & 180 \\
\hline \multirow{3}{*}{ Clay soil } & ${ }^{14} \mathrm{C}$-phenanthrene & 100.0 & 99.4 & 98.1 & 97 & 98.4 \\
\hline & 9,10-phenanthrenedione & 0 & 0.5 & 1.7 & 2.6 & 1.4 \\
\hline & Others & 0 & 0.1 & 0.2 & 0.4 & 0.2 \\
\hline \multirow{3}{*}{ Sandy loam soil } & ${ }^{14} \mathrm{C}$-phenanthrene & 100.0 & 99.0 & 97.6 & 96.5 & 97.9 \\
\hline & 9,10-phenanthrenedione & 0 & 0.8 & 2.2 & 3 & 1.8 \\
\hline & Others & 0 & 0.2 & 0.2 & 0.5 & 0.3 \\
\hline
\end{tabular}

events that affect soil humidity influence other processes such as degradation or volatilisation. Thus, the production of degradation products, which are more mobile than the parent molecule, or the elimination of phenanthrene by volatilisation during hot dry periods, also indirectly influence leaching.

\subsection{Polar ${ }^{14} \mathrm{C}$-compounds in leachates}

After a 20-day period and until the end of the experiment, $50 \%$ to $80 \%$ of the radioactivity present in the leachates were not extracted by liquid/liquid partitioning and can consequently be characterised as polar residues. Thus, the majority of the residues leached are polar. The fraction of polar compounds is about the same for the two soils. The quantities leached were too small to allow further analysis by HPLC. Nevertheless, some hypotheses can be proposed about the existence of polar residues. The existence of polar residues suggests that chemical or biological degradation of the phenanthrene occurs or that it is bound to less hydrophobic compounds.

\subsection{Extractable ${ }^{14} \mathrm{C}$-phenanthrene residues from the soils}

The decrease in extractable ${ }^{14} \mathrm{C}$-phenanthrene residues over time was similar for the two soils (Fig. 4). A large quantity of residues remained extractable for up to 30 days and then decreased in a very significant way at 90 days and rose slightly at 180 days. At 30 days, we observed $54 \%$ of extractable residues in the clay soil and $60 \%$ in the sandy loam soil. With longer contact times, the amounts of extracted residues decreased, and were less than $20 \%$ in the clay soil and $9 \%$ in the sandy loam soil after 180 days.

The decrease in the extractable residues was not correlated with variations in the concentrations of residual leachate, as shown above (Fig. 3). This underlines the major role of the process of degradation which, by the formation of polar residues, more soluble and less retained by the soil, favours the leaching.

\subsection{Extractable ${ }^{14} \mathrm{C}$-compounds in the soil analysis}

Analysis by high-performance liquid chromatography (HPLC) of the extracted compounds showed that only one degradation product was present in significant quantities (Tab. V). This was 9,10-phenanthrenedione, which accounted for 0.5 to $3 \%$ of the

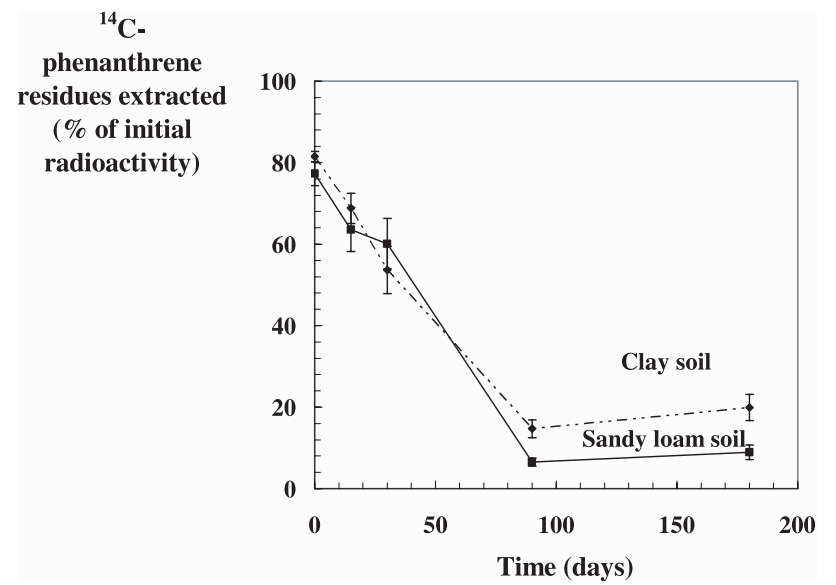

Figure 4. Changes in ${ }^{14} \mathrm{C}$-phenanthrene residues extractable with methanol from two soils during a six-month experiment using a microlysimeter and in outdoor conditions.

extractable residues; there was no correlation with the contact time or the soil type. This product is strongly toxic for the flora and the fauna of the soil (McConkey et al., 1997). However, 9,10-phenanthrenedione is practically insoluble in water and thus presents few risks of contamination of the soil water. It contributes probably to the formation of bound residues or it is degraded later. This result does not exclude the possible presence of other products at concentrations lower than the quantification limit $(5400 \mathrm{~Bq} / 100 \mu \mathrm{L})$.

The very low quantities of degradation products can be interpreted in different ways: (1) slight degradation of phenanthrene in both soils, (2) the leaching of the majority of the metabolites (more soluble in water) before sampling of the soil columns for analysis, and (3) the rapid sequestration of the degradation products (Weigand et al., 2002).

\subsection{Dynamics of formation of ${ }^{14} \mathrm{C}$-phenanthrene- bound residues in soils}

Bound residues were detected immediately after application of the chemical, as shown in Figure 5. Bound residues in the two soils increased rapidly over time, the highest level being observed at 90 days, followed by a non-significant decrease up to day $180(P<0.05)($ Fig. 5). This implies that one fraction of 


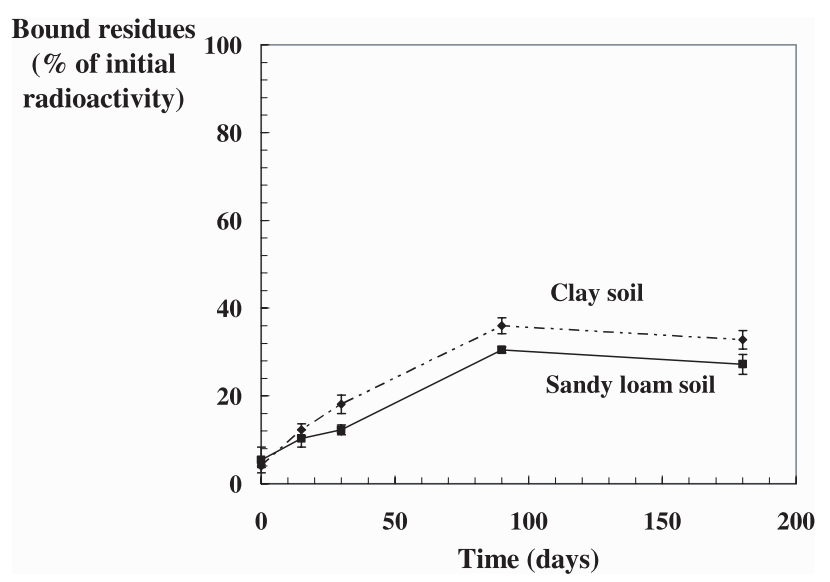

Figure 5. Evolution of the formation of bound residues (\% of initial radioactivity) measured in two soils during 180 days of contact time.

these residues is still, perhaps, potentially available. The bound residue fraction formed in the sandy loam soil was found to be significantly lower $(P<0.05)$ than in the clay soil. This may be the consequence of a higher percentage of organic carbon in the clay soil $(1.9 \%)$ than in the sandy loam soil $(0.8 \%)$. The formation of bound residues is linked to the presence of soil organic matter because of its large number of sorption-specific sites (Pignatello, 1998). Nevertheless, the clay soil exhibited more significant microporosity which could facilitate the physical entrapment of the phenanthrene. Binding of the residues may have contributed to the decrease observed in the leachate rates after 100 days of contact time in both soils.

However, the balance of the measured radioactivity presented a deficit that increased with time: close to $15 \%$ at the beginning and to $40 \%$ at the end of the experiment. This suggests that one fraction (around 15\%) of the phenanthrene is volatilised when the soil is contaminated and another fraction during the experiment. Yet another fraction was mineralised. The latter could be estimated in laboratory experiments.

\section{CONCLUSION}

The experiment we performed in natural climatic conditions demonstrated that in spite of its solubility in water of $1.1 \mathrm{mg} / \mathrm{L}$, after 6 months the quantities of phenanthrene residues leached in the agricultural soils studied were low; $2 \%$ of the amount of radioactivity applied. This is due to its strong adsorption and weak desorption capacity. Consequently, in the leachates of microlysimeters, phenanthrene represented only a limited proportion, from 20 to $40 \%$. Leaching primarily concerned degradation products, maybe including traces of 9,10-phenanthrenedione, which was present in significant quantities in the soils in an extractable state.

\section{REFERENCES}

Barriuso E., Calvet R., Schiavon M., Soulas G. (1996) Les pesticides et les polluants organiques des sols, transformation et dissipation, Étude et Gestion des Sols 34, 279-296.
Batjes N.H. (1998) World Reference Base for Soil Resources, ISRIC, FAO, ISSS ${ }^{\circledR}$ and Acco, Leuven, Belgium.

Chiou C.T., Kile D.E., Rutherford D.W., Sheng G., Boyd S.A. (2000) Sorption of selected organic compounds from water to a peat soil and its humic-acid and humin fractions: potential sources of the sorption nonlinearity, Environ. Sci. Technol. 34, 1254-1258.

Coquet Y. (2002) Variation of pesticide sorption isotherm in soil at the catchment scale, Pest. Manag. Sci. 59, 69-78.

Crépineau-Ducoulombier C., Rychen G. (2003) Assessment of soil and grass Polycyclic Aromatic Hydrocarbons (PAHs) contamination levels in agricultural fields located near a motorway and airport, Agronomie 23, 345-348.

Fent K. (2004) Ecotoxicological effects at contaminated sites, Toxicology 205, 223-240.

Guennelon R. (1994) Le sol et l'eau, in: Bonneau M., Souchier B. (Eds.), Pédologie 2. Constituants et propriétés du sol, Masson, Paris, pp. 395-428.

Jacquin F., Florentin L. (1988) Atlas des sols de Lorraine, Presses Universitaires de Nancy.

Johnsen A., Wick L.Y., Harms H. (2004) Principles of microbial PAHdegradation in soil, Environ. Pollut. 133, 71-84.

Jones K.C., Stratford J.A., Tidridge P., Waterhouse K.S., Johnston A.E. (1989) Polynuclear aromatic hydrocarbons in an agricultural soil: long-term changes in profile distribution, Environ. Pollut. 56, 337351 .

Laurent C., Feidt C., Grova N., Mpassi D., Lichtfouse E., Laurent F., Rychen G. (2002) Portal absorption of ${ }^{14} \mathrm{C}$ after ingestion of spiked milk with ${ }^{14} \mathrm{C}$-phenanthrene, ${ }^{14} \mathrm{C}$-benzo[a]pyrene or ${ }^{14} \mathrm{C}$-TCDD in growing pigs, Chemosphere 48, 843-848.

Lichtfouse E., Schwarzbauer J., Robert D. (2005) Environmental Chemistry, Springer.

Lichtfouse E., Budzinski H., Garrigues P., Eglinton T.I. (1997) Ancient polycyclic aromatic hydrocarbons in modern soils: ${ }^{13} \mathrm{C},{ }^{14} \mathrm{C}$ and biomarker evidence, Org. Geochem. 26, 353-359.

Magee B.R., Lion L.W., Lemley A.T. (1991) Transport of dissolved organic macromolecules and their effect on the transport of phenanthrene in porous media, Environ. Sci. Technol. 25, 323-331.

McConkey B.J., Duxbury C.L., Dixon D.G., Greenberg B.M. (1997) Toxicity of PAH photooxidation product to the bacteria Photobacterium phosphoreum and the Duckweed lemna gibba: Effects of phenanthrene and its primary photoproduct, phenanthrenequinone, Environ. Toxicol. Chem. 16, 892-899.

Monnier G. (1994) Assemblage et organisation des particules, in: Bonneau M., Souchier B. (Eds.), Pédologie 2. Constituants et propriétés du sol, Masson, Paris, pp. 325-348.

OECD (2000) Adsorption/desorption using a batch equilibrium method, test guideline 106, OECD guidelines for testing of chemicals, OECD Publications, Paris.

Perera F.P. (1997) Environment and cancer: Who are susceptible? Science 278, 1068-1073.

Pignatello J.J. (1998) Soil organic matter as a nanoporous sorbent of organic pollutants, Adv. Colloid Interfac. 76-77, 445-467.

Reeves W.R., McDonald T.J., Cizmas L., Donnelly K.C. (2004) Partitioning and desorption behavior of polycyclic aromatic hydrocarbons from disparate sources, Sci. Total Environ. 332, 183-192.

Saison C., Perrin-Ganier C., Amellal S., Morel J.L., Schiavon M. (2004) Effect of metals on the adsorption and extractability of ${ }^{14} \mathrm{C}$-phenanthrene in soils, Chemosphere 55, 477-485. 
Samsøe-Petersen L., Larsen E.H., Larsen P.B., Bruun P. (2002) Uptake of trace elements and PAHs by fruit and vegetables from contaminated soils, Environ. Sci. Technol. 36, 3057-3063.

Weigand H., Totsche K.U., Huwe B., Kogel-Knabner I. (2001) PAH mobility in contaminated industrial soils: a Markov chain approach to the spatial variability of soil properties and PAH levels, Geoderma 102, 371-389.

Weigand H., Totsche K.U., Huwe B., Kogel-Knabner I., Richnow H.H. (2002) Fate of anthracene in contaminated soil: transport and biochemical transformation under unsatured flow conditions, Eur. J. Soil Sci. 53, 71-81.

Wilcke W., Zech W., Kobza J. (1996) PAH-pools in soils along a PAHdeposition gradient, Environ. Pollut. 92, 307-313.
Wild S.R., Jones K.C. (1995) Polynuclear aromatic hydrocarbons in the United Kingdom environment: A preliminary source inventory and budget, Environ. Pollut. 88, 91-108.

Wild S.R., Waterhouse K.S., McGrath S.P., Jones K.C. (1990) Organic contaminants in an agricultural soil with a known history of sewage sludge amendments: Polynuclear aromatic hydrocarbons, Environ. Sci. Technol. 24, 1706-1711.

Worrall F., Fernandez-Perez M., Johnson A.C., Flores-Cesperedes F., Gonzalez-Pradas E. (2001) Limitations on the role of incorporated organic matter in reducing pesticide leaching, J. Contam. Hydrol. $49,241-262$.

Zehe E., Fluhler H. (2001) Preferential transport of isoproturon at a plot scale and a field scale tile-drained site, J. Hydrol. 247, 100-115.

To access this journal online: www.edpsciences.org 